\title{
Silurian tectonic history of Penobscot Bay region, Maine
}

\author{
David B. Stewart ${ }^{1}$, John D. Unger ${ }^{1}$, and Deborah R. Hutchinson ${ }^{2}$ \\ 1 U.S. Geological Survey, Reston, Virginia 22092, U.S.A. \\ 2 U.S. Geological Survey, Woods Hole, Massachusetts 02543, U.S.A.
}

Date Received January 30, 1995

Date Accepted September 18, 1995

Early Paleozoic amalgamation of composite terranes was contemporaneous at widely separated regions that were later accreted to either ancestral North America or to Gondwana as those two continents approached each other. Terranes closer to Laurentia amalgamated in the Late Cambrian to Middle Ordovician Penobscottian orogeny and were accreted to ancestral North America in the Middle and to Late Orodovician Taconic orogeny. PeriGondwanan terranes formed from Late Cambrian and Early Ordovician rocks were amalgamated in the Late Ordovician and Early Silurian to form the Salinic orogenic belt, now exposed from western Europe to southern New England. Salinic orogenic activity involved extensive thrust faulting and metamorphism, large strike-slip faults, and plutonism, all of which are represented in coastal Maine. In the Penobscot Bay region, Maine, the periGondwanan St. Croix terrane was thrust northwest in the Silurian(?) upon middle amphibolite facies Ordovician and Early Silurian rocks of the Fredericton trough. Seismic reflection profiles show that the thrust fault dips southeasterly at $\sim 30^{\circ}$ and becomes listric at about $13 \pm 2 \mathrm{~km}$. The thrust sheet was broken initially by the Late Silurian Penobscot Bay-Smith Cove-North Blue Hill dextral strike-slip fault which juxtaposed the peri-Gondwanan Ellsworth terrane, followed by emplacement of the South Penobscot Intrusive Suite and by a sequence of strikeslip fault zones each with up to $20 \mathrm{~km}$ of dextral Silurian and Early Devonian(?) movement. The strike-slip faults are interpreted to either remain steep until they reach the sole of the thrust sheet or to become listric within the thrust sheet. In the Devonian Acadian orogeny, more outboard terranes with Gondwanan affinities, like the Avalonian terranes in southern New Brunswick and in eastern Massachusetts, were amalgamated with the Silurian orogenic belt, and the resulting composite terrane was accreted to ancestral North America. Acadian deformation, metamorphism, and plutonism are superimposed on the Silurian orogen, blurring or obliterating the evidence of Silurian orogeny.

Le fusionnement du Paléozoïque inférieur des formations géologiques composites a été simultané dans des régions très séparées qui ont ultérieurement été accolées, soit à l'Amérique du Nord ancestrale, soit au Gondwana, au fur et à mesure que les deux continents se sont rapprochés l'un de l'autre. Les formations géologiques plus proches du bouclier laurentien se sont fusionnées à l'Amérique du Nord au cours de l'orogénèse Taconique de l'Ordovicien moyen à supérieur. Les formations géologiques périgondwaniennes formées de roches du Cambrien supérieur à l'Ordovicien inférieur ont été fusionnées au cours de l'Ordovicien supérieur et du Silurien inférieur pour former la ceinture orogénique Salinique, maintenant découverte à partir de l'Europe occidentale jusqu'au sud de la Nouvelle-Angleterre. L'activité orogénique salinique a comporté un métamorphisme et une dislocation de compression importants, des décrochements étendus et le plutonisme, des phénomènes qui sont tous représentés sur la côte du Maine. Dans la région de Penobsquot Bay, au Maine, la formation géologique périgondwanienne de St. Croix a été poussée vers le nord-ouest pendant le Silurien (?) sur les roches de l'Ordovicien et du Silurien inférieur du faciès intermédiaire à amphibolite de la dépression de Fredericton. Les profils de réflexion sismique montrent que la faille de compression s'incline vers le sud-est selon un angle de $30^{\circ}$ et qu'elle devient courbe après environ $13 \pm 2 \mathrm{~km}$. La nappe avait initialement été fracturée par le décrochement dextre du Silurien supérieur de Penobsquot Bay-Smith Cove-North Blue Hill qui avait juxtaposé la formation périgondwanienne d'Ellsworth, événement suivi par le positionnement du cortège intrusif de South Penobsquot et par une séquence de zones de décrochements accusant chacun jusqu'à $20 \mathrm{~km}$ de déplacement dextre au cours du Silurien et du Dévonien inférieur (?). On interprète les décrochements comme des accidents qui restent abrupts jusqu'à ce qu'ils atteignent la surface inférieure de la nappe ou comme des failles devenant courbes à l'intérieur de la nappe. Au cours de l'orogénèse Acadienne du Dévonien, d'autres formations géologiques extérieures ayant des affinités avec le Gondwana, comme la formation géologique d'Avalon, dans le sud du Nouveau-Brunswick, et dans l'est du Massachusetts, ont été fusionnées avec la ceinture orogénique Silurienne, et la formation composite qui en est résultée a été accolée à l'Amérique du Nord ancestrale. La déformation, le métamorphisme et le plutonisme Acadiens sont superposés par-dessus l'orogène du Silurien, ce qui efface et brouille la preuve de l'orogénèse Silurienne.

[Traduit par la rédaction] 


\section{INTRODUCTION}

Early in the Paleozoic, plate tectonic motions of the very large Laurentian and Gondwanan continents caused each to accrete some of the many tectonostratigraphic terranes that had existed between them. Some composite terranes were formed before being accreted to a continent. Subsequent collision of the continents and their accreted terranes created the supercontinent Pangea and formed the Appalachian orogen, as much as $700 \mathrm{~km}$ wide in places. An ever more complex, though still incomplete, description of the processes that formed the Appalachian orogen is being achieved as such distinguishing characteristics as the faunal affinities and depositional, isotopic, paleomagnetic, and seismic reflection properties of the component terranes are recognized and integrated with precise geochronologic data. It is clear that, over the same geologic time interval, many of the terranes between the continents experienced very different sedimentary, metamorphic and plutonic regimes. The geologic time scale of Tucker and McKerrow (1995) will be used throughout this paper; the Ordovician and Silurian age ranges are known to within 2 or $3 \mathrm{~m} . \mathrm{y}$. The orogen is now recognized (van Staal and Williams, 1992) to have originated from a spectrum of processes most like those active today in the western Pacific Ocean, where an array of island arcs, back-arc basins, oceanic terranes and even microcontinental blocks are juxtaposed by faults of many types, some with long translational movements.

It is now known that the rocks underlying coastal Maine were not affected by the Middle and Late Ordovician Taconian orogeny that affected rocks elsewhere in the Appalachian orogen. Rocks in the region of Penobscot Bay, Maine, contain a complex history of Silurian and Early Devonian(?) terrane accretion and fault movements that can be best explained as part of a Silurian orogenic belt that developed along the margin of Gondwana prior to the Devonian Gondwana-Laurentia collision. West et al. (1992c) determined that the periGondwanan terranes in southeastern Maine had been amalgamated into a composite terrane by Late Silurian time, prior to the Acadian orogeny. It is the purpose of this paper to describe the rocks in Penobscot Bay that were affected by Silurian tectonism, to describe the extent of these rock units within the crust, and speculate on their regional correlations and significance.

A detailed geologic map and cross sections for the Penobscot Bay region, and gravity, magnetic, and seismic reflection and refraction data sets for the same region have been prepared (Stewart, in press). Some of the principal results are given here. The 24-fold multichannel seismic reflection data for line 8 (USGS Gyre 85-11-8) were collected by the U.S. Geological Survey in 1985 with a 2-airgun source $\left(1080 \mathrm{in}^{3}\right)$ fired every $25 \mathrm{~m}$, a $1200 \mathrm{~m}$ streamer, and recorded for $6 \mathrm{sec}-$ onds. Processing followed standard industry techniques. Multichannel reflection line USGS 3B was collected in 1983; a $90 \mathrm{~m} \mathrm{sc}$ urce interval and 800 recording channels at $30 \mathrm{~m}$ spacing were recorded for 15 seconds. Processing was described by Spencer et al. (1989, table 3).

\section{TECTONIC FRAMEWORK}

Interpretations that the Appalachian orogen formed by the accretion of successively younger outboard terranes during three principal and discrete Paleozoic events have proved inadequate as discussed by van Staal (1993) and Rankin (1994). North of the Hudson River, the Middle and Late Ordovician Taconian orogeny caused the accretion of several island arcs, back-arc basins and fragments of oceanic terranes of different Cambrian and Early Ordovician ages that contained sparse fauna of Laurentian (North American) affinity. In northern Maine and southeastern Quebec, a composite terrane made up of Middle Cambrian to Early Ordovician rocks (Boone and Boudette, 1989) had amalgamated before the Taconian orogeny, and was subsequently accreted to Laurentia. Farther east (present directions) in the Miramichi Highlands of central New Brunswick there is no evidence for the Taconian orogeny: van Staal (1987) and van Staal and Fyffe (1991) described a quite different orogenic belt with sandstone and shale of Late Cambrian and Early Ordovician age containing detrital zircons of Late Proterozoic Pan-African age and interpreted to have been deposited close to Gondwana. These rocks are unconformably overlain by Middle Ordovician basalts and shales that contain peri-Gondwanan Celtic fauna (Neuman and Harper, 1992). In the Late Ordovician and Early Silurian a wide back-arc basin containing these rocks was closed, with thrusting toward the southeast to form a complex 'Salinic' orogen underlain by Gondwanan continental rocks (van Staal, 1994). Evidence for a Silurian orogenic belt is also found in Nova Scotia (Reynolds et al., 1989; Dunning et al., 1990a), southern and eastern Newfoundland (Dunning et al., 1990b; O'Brien et al., 1991), and in the Caledonides of Scotland and Scandinavia (Dunning et al., 1990a).

Parts of the Silurian orogenic belt formed spatially removed from ancestral North America proximal to, but not necessarily amalgamated with Gondwana, a continental mass with a basement of Late Proterozoic gneisses and granitic plutons covered in places by thick sections of Late Proterozoic and Cambrian bimodal rift volcanic rocks and in other places by thin Late Proterozoic to Ordovician platformal sedimentary rocks with an Old World (or Acado-Baltic) circumpolar faunal assemblage (Secor et al., 1989; Goldsmith and Secor, 1993). Tectonism in the Silurian along the margins of Gondwana involved extensive thrust faulting and metamorphism and large strike-slip faults (O'Brien et al., 1991; Nance and Dallmeyer, 1993; Dunning et al., 1993; Dubé et al., 1993; van Staal, 1994), intrusion of bimodal sheeted dikes (Eby and Currie, 1993; Doig et al., 1990), formation of thick crust and extensive plutonism (Bevier and Whalen, 1990). Rocks from Penobscot Bay in coastal Maine were affected by these processes (Stewart, in press).

The Fredericton trough is a sedimentary basin formed in the southeastern part of the Salinic orogen in New Brunswick and southeastern Maine (Ludman, 1986; Ludman et al., 1993). The Central Maine synclinorium (Fig. 1) is presently exposed west of the Silurian orogenic belt described here and was the 


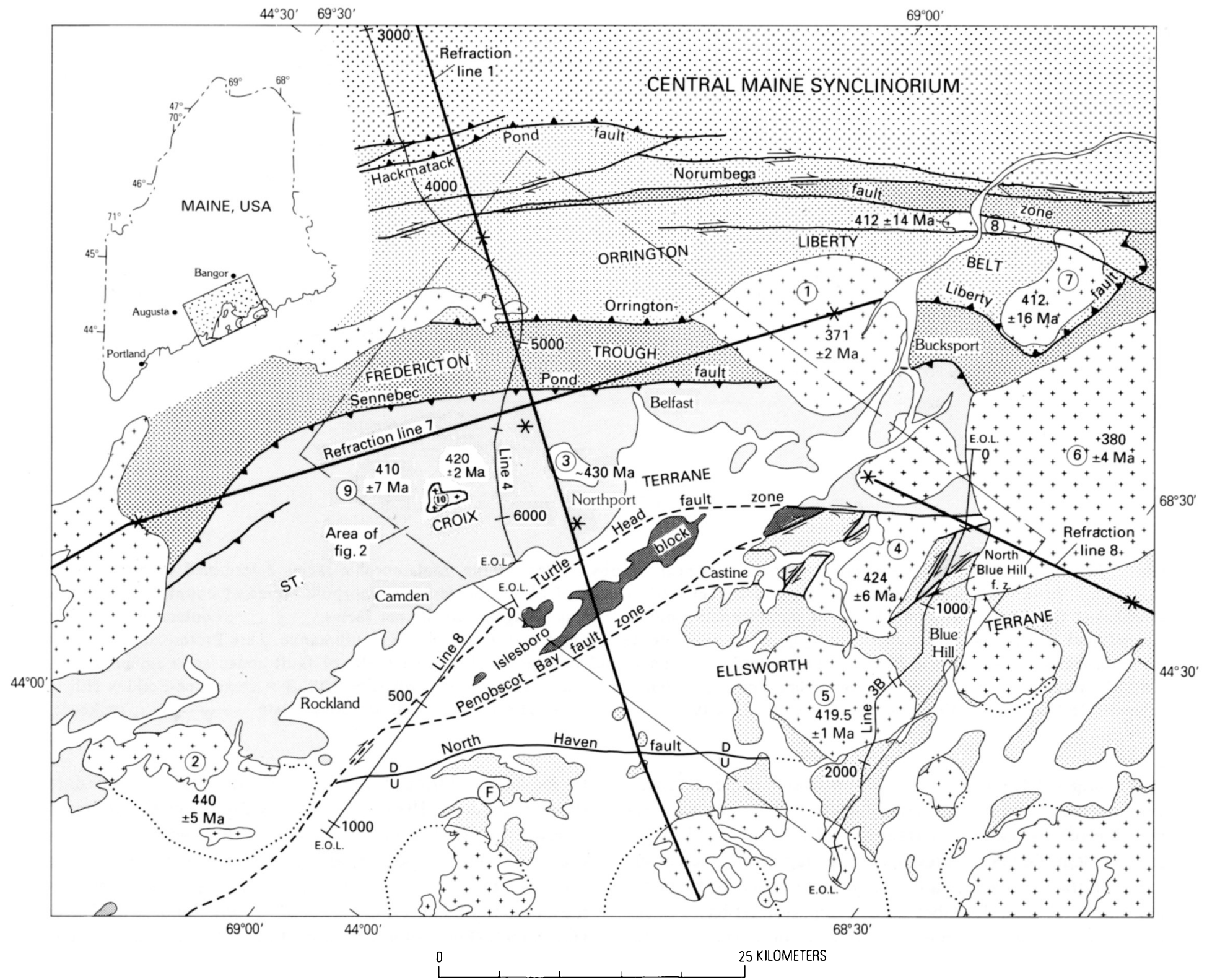

Fig. 1. Simplified geologic map of the Penobscot Bay region, south-central Maine showing tectonostratigraphic terranes, principal faults, and locations of vertical incidence seismic reflection lines (numbers at common midpoint locations, E.O.L. = end of line) and seismic refraction lines (asterisk at shot points). The seismic reflection profile along line 8 is shown on Figure 3 , and that along line 3B is shown in Figure 4. The Orrington-Liberty belt and the Fredericton trough are two components of the Nashoba-Casco-Miramichi composite terrane of Stewart et al. (1993); the Norumbega fault zone lies within this composite terrane. Plutons specifically discussed in text are numbered (with only $\mathrm{Pb}-\mathrm{U}$ zircon dates shown, $\mathrm{Rb}-\mathrm{Sr}$ dates not shown): $1=$ Mount Waldo pluton, $2=\mathrm{Spruce}$ Head pluton, $3=$ Northport pluton, $4=$ South Penobscot Intrusive Suite, $5=$ Sedgwick pluton, $6=$ Lucerne pluton, $7=$ granite of Stricklen Ridge, 8 = Winterport pluton, $9=$ quartz diorite at Union, $10=$ Youngtown pluton. Site of Acado-Baltic fossils on North Haven Island shown by F. Sources for reflection and refraction data are cited in text except for refraction line 7 , Klemperer and Luetgert (1987). Outline of area shown on Figure 2 is shown by dashed line.

site of continuous sedimentation from Late Ordovician to Early Devonian time (Berry and Osberg, 1989). The complex tectonic history of the Penobscot Bay region (Figs. 1, 2) took place during this same time interval. Thus it is unlikely that these two areas were immediately adjacent to one another during this time. The Devonian Acadian orogeny brought together areas with different pre-Devonian histories. Post-Silurian deformations (West et al., 1993), metamorphism (Guidotti, 1989), and plutonism have obscured evidence of earlier pro- cesses. However, in the Penobscot Bay region of Maine much of the pre-Silurian and Silurian history is preserved because Acadian overprinting is weak or absent.

\section{Terranes in the Penobscot Bay region}

The geology of coastal Maine is made up of large geologic entities, such as terrane, block, belt, trough or synclinorium. We have used tectonostratigraphic terrane, or 

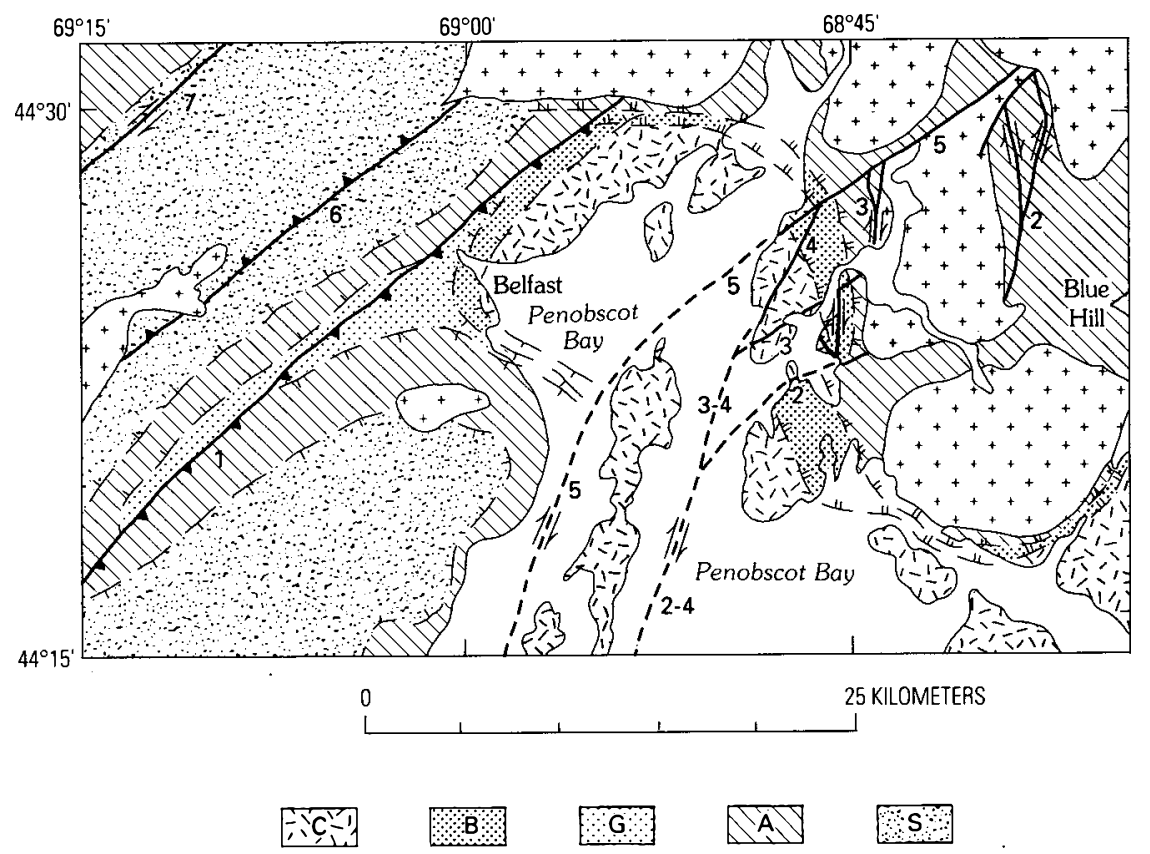

Fig. 2. Map of metamorphic facies and principal faults near Penobscot Bay, Maine. Metamorphic facies determined by petrographic studies by Stewart (in press) east of $69^{\circ} \mathrm{W}$, and Bickel (1976) west of $69^{\circ} \mathrm{W}$. Lowest metamorphic facies of country rock is low greenschist facies $(\mathrm{C}=$ chlorite). Regional metamorphic isograds, tick pointing toward higher facies, _1_ c contact metamorphic isograds tick points toward higher facies, ․․ $. \mathrm{B}=$ biotite, $\mathrm{G}=$ garnet, $\mathrm{A}=$ andalusite, $\mathrm{S}=$ sillimanite. Late Proterozoic basement metamorphism of Islesboro at lower amphibolite facies (andalusite) not shown. Principal faults or fault zones are numbered from oldest to youngest inferred age: 1 = Sennebec Pond, 2 = Penobscot Bay-Smith Cove-North Blue Hill, 3 = Bagaduce-Perkins Hill, 4 $=$ North Castine, $5=$ Turtle Head, $6=$ Orrington-Liberty, $7=$ Norumbega. Thrust fault (teeth on upper plate fault $-\underline{\underline{-}}$ ).

more simply, terrane for large fault-bounded regional tracts, each characterized by a different history than contiguous terranes. Block is used for a fragment of a terrane of less regional extent. Belt designates an elongate region in which original stratigraphic features and relations are obscured by metamorphism. Trough describes a large depositional basin of regional extent, and synclinorium defines a composite synclinal structure of regional extent composed of smaller folds.

Tectonostratigraphic terranes in the region are elongated subparallel to the northeasterly trend of the orogen (Fig. 1), and their original widths have been reduced by later folding and faulting. The characteristics of each of these terranes are discussed in Stewart et al. (1993) and Stewart (in press). Brief descriptions of the principal terranes to be discussed are given here, starting with the Ellsworth terrane in the southeastern part of the region (Fig. 1).

The Ellsworth terrane is composed of as many as three sequences of mostly volcaniclastic rocks deposited upon an unknown basement. The oldest is the Ellsworth Schist of late Middle Cambrian age (Stewart et al., 1995). Ellsworth Schist is a predominantly marine bimodal tholeiitic basalt-rhyolite in-plate continental rift sequence with interbedded metasiltstone, quartzite, iron-, and manganese-rich schistose chemical precipitates, and rare marble. After folding and greenschist facies metamorphism, the Ellsworth Schist was unconformably overlain by the Castine Volcanics, another bimodal basalt-rhyolite continental rift sequence that also contains interbedded marine to subaerial volcaniclastic rocks and ferroan and manganiferous sedimentary rocks. Although these rocks have yielded a Late Cambrian $\mathrm{U}-\mathrm{Pb}$ zircon date (Ruitenberg et al., 1993), they are only slightly metamorphosed to lower greenschist (chlorite) facies. The Castine Volcanics texturally and compositionally closely resemble the Middle Silurian volcanic rocks exposed in the Ellsworth terrane on the Cranberry Islands (Seaman et al., 1995). South of the North Haven fault (Fig. 1) another suite of fossiliferous volcaniclastic sedimentary rocks ( $\mathrm{F}$ on Fig. 1) at lower greenschist facies contains a diverse Middle Silurian to Early Devonian fauna of peri-Gondwanan (Acado-Baltic) affinity (Brookins et al., 1973). The presence of this faunal assemblage is the principal reason for calling the Ellsworth terrane a peri-Gondwanan terrane.

The Islesboro block contains a cover sequence of platformal or shallow water slope-rise metasedimentary rocks interpreted by Stewart (in press) to have been deposited unconformably on a Proterozoic basement. The basement is made up of quartzite, feldspathic quartzite, dolomitic marble, splendent muscovite-garnet-staurolite-andalusite schist, hornblende-garnet amphibolite and phlogopite gneiss. The ${ }^{40} \mathrm{Ar} /$ ${ }^{39} \mathrm{Ar}$ hornblende release spectra, though discordant, were interpreted by Stewart and Lux (1988) to date cooling following amphibolite facies metamorphism as Late Proterozoic ( 670 to $650 \mathrm{Ma}$ ). These are the oldest rocks known in Maine. This basement has been extensively retrograded to lower greenschist facies equivalent to that in the cover sequence.

The cover sequence of the Islesboro block is metasiltstone interbedded with sandstone that may be either feldspathic (and/ or) calcareous. Several sequences of siliceous dolomitic lime- 
stone, a few volcanogenic wackes and a felsic tuff occur in the section. Many beds of quartzite and conglomerates with quartzite pebbles and cobbles are interbedded with the siltstone, sandstone and siliceous dolomite. Only lower greenschist facies metamorphism (chlorite- or chloritoid-bearing rocks) occur in the cover sequence of the Islesboro block (Stewart, in press).

The Islesboro block has similarities in lithology, style of deformation, and metamorphic grade to the Ellsworth Schist, which is the oldest sequence of volcanic rocks in the Ellsworth terrane. The Islesboro block may be equivalent to the Ellsworth terrane, but originally was located distal to the volcanic-rich Ellsworth terrane. In southern Islesboro, strike-slip faulting along the Penobscot Bay fault (number 2 on Fig. 2) and related faults has juxtaposed blocks of Ellsworth terrane and the Islesboro block. However, the rocks of the Islesboro block are sufficiently different in lithology from the Ellsworth terrane that Stewart (in press) named the Islesboro block as a separate entity, although it is probably too small to warrant being called a tectonostratigraphic terrane. We hypothesize that the rocks of the Islesboro block may be a distal facies of the Ellsworth Schist of the Ellsworth terrane. Osberg and Berry (1991) interpreted rocks of the Islesboro block to be equivalent to rocks exposed on the mainland near Rockland (Fig. 1). However, this would seem to require that motion along the Turtle Head fault zone was left lateral; in the next section it will be argued that this fault zone had principally right-lateral strike-slip.

The St. Croix terrane (Ludman, 1987) contains rocks that were deposited along a continental slope. Some were deposited in deep anoxic water concurrently with minor basaltic volcanism having within-plate tholeiitic geochemical characteristics (Fyffe et al., 1988). The St. Croix terrane in the region under discussion consists of thin-bedded metasandstone, graphitic and pyrite- or pyrrhotite-bearing metapelite, and a few calcareous quartzites or marble beds. Several basalt flows occur near the base of the section (Fyffe et al., 1988). The St. Croix terrane along strike to the northeast correlates with rocks of Ordovician age (Fyffe and Riva, 1990; Ludman, 1991, 1987). South and southwest of Belfast, the Penobscot Formation was folded and metamorphosed to as high as upper amphibolite facies in possibly two episodes that were no younger than Early Silurian. R.E. Zartman (written communication, 1991) obtained a U-Pb age of $440 \pm 5 \mathrm{Ma}$ age for the nonfoliated Spruce Head pluton (number 2 on Fig. 1) that intrudes rocks of the St. Croix terrane near Rockland, Maine. West et al. (1992a, in press) obtained Middle Silurian ${ }^{40} \mathrm{Ar} /{ }^{39} \mathrm{Ar}$ cooling dates on hornblende from country rocks near this pluton. Ericksson et al. (1989) reported an Early Silurian U-Pb zircon age $(\sim 430 \mathrm{Ma})$ from the post-kinematic granite of Northport (number 3 on Fig. 1) that intrudes folded and metamorphosed Penobscot Formation, and R.D. Tucker (written communication, 1995) obtained a Late Silurian age for the Youngtown pluton (number 10 on Fig. 1). Northeast of Belfast, the Penobscot Formation is metamorphosed to greenschist and epidote amphibolite facies (Fig. 2) and locally the biotite isograd is subparallel to the trace of the Sennebec Pond fault.

The rocks of the Fredericton trough in this area are the Bucksport Formation and Appleton Ridge Formation. These formations intertongue in places (Stewart, in press) and are partly equivalent in age. The Bucksport Formation is correlated along strike to the northeast with the Upper Ordovician and Lower Silurian Flume Ridge Formation (West et al., 1992c; Fyffe, 1992a, 1992b). West of Penobscot Bay the rocks of the Fredericton trough are regionally metamorphosed to low and middle amphibolite facies (Fig. 2), but north and east of Bucksport (Fig. 1), Fredericton trough rocks are at greenschist facies, except in the contact aureoles of younger plutons. Regional metamorphism of Fredericton trough rocks to lower and middle amphibolite facies may have occurred in the Silurian (Stewart et al., 1995).

\section{TERRANe-Bounding faults in the Penobscot Bay region}

Major faults, some with long histories of movement, bound the terranes. The most important of these faults in the Penobscot Bay region will be discussed from oldest to youngest according to their inferred age sequence as shown by the numbers on Figure 2.

\section{Sennebec Pond thrust fault}

Rocks of the St. Croix terrane (Ludman, 1987) are thrust upon rocks of the Fredericton trough by the Sennebec Pond thrust fault (Hussey, 1989, p. 36; same as St. George fault of Bickel, 1976), designated number 1 on Figure 2. Geologic relations deduced for the Penobscot Bay region suggest that the Sennebec Pond thrust fault is the oldest fault and that it is of Silurian age (Stewart, in press). However, the fault could be as young as Early Devonian based on available geochronologic data. The Sennebec Pond fault is intruded by the Mount Waldo pluton; this pluton also cuts the Orrington-Liberty fault (number 6 on Fig. 2), one of the younger faults in the region. The U-Pb zircon age recently determined for the Mount Waldo pluton by R.D. Tucker is $371 \pm 2 \mathrm{Ma}$ (Middle Devonian) (Stewart et al., 1995). The Rb-Sr whole rock age for the Mount Waldo pluton (Brookins, 1976) is $382 \pm 10 \mathrm{Ma}$, recalculated with the $\mathrm{Rb}^{87}$ decay constant of $1.42 \times 10^{-11} / \mathrm{yr}$. The Sennebec Pond fault now dips very steeply to the southeast and its map trace is not affected by regional topography. Even though it originated as a thrust fault, it may have been rotated toward a steeper angle by compression in later events. Evidence from seismic reflection profiles discussed below indicates that at depth it dips southeast less steeply.

Southwest of Belfast (Fig. 2), Bickel (1976) showed that the Sennebec Pond fault breaks lower and middle amphibolite facies isograds in the St. Croix terrane, which indicates that the metamorphism is older than the fault. Isograds within lower amphibolite facies rocks of the Fredericton trough are also broken by the fault.

Northeast of Belfast, large crystals of the lower amphibolite facies minerals staurolite, andalusite and garnet from rocks of the Fredericton trough are milled together with greenschist and epidote-amphibolite facies rocks of the St. Croix terrane along the Sennebec Pond fault. The biotite isograd in the Penobscot Formation of the St. Croix terrane is subparallel to 
the trace of the Sennebec Pond fault. Stewart (in press) suggested that heat flow from still-hot Fredericton trough metamorphic rocks could have caused metamorphism of the Penobscot Formation just emplaced by the Sennebec Pond fault.

In eastern Maine, West et al. (1992c) have argued that the Middle Silurian Pocomoonshine gabbro-diorite of Westerman (1991) was intruded across a fault equivalent to the Sennebec Pond fault where rocks of the St. Croix terrane are thrust against rocks of the Fredericton trough.

\section{Penobscot Bay-Smith Cove-North Blue Hill and Bagaduce-Perkins Hill strike-slip faults}

A complex zone of Silurian right-lateral strike-slip faults juxtaposes rocks of the St. Croix terrane with rocks of another peri-Gondwanan terrane, the Ellsworth terrane (Fig. 1). Evidence for overall dextral movement in this complex fault zone includes the offset of identifiable formations (Stewart, in press) and isograds (Fig. 2), and the shear sense of numerous minor folds, slip cleavage, and microstructural kinematic indicators such as asymmetric tails around large mineral grains. The earliest phase of movement was along the Penobscot Bay-Smith Cove-North Blue Hill fault zone (number 2 on Fig. 2). This fault zone is $3 \mathrm{~km}$ or more wide, and contains blocks as large as $7 \mathrm{~km}$ long and $2.5 \mathrm{~km}$ wide (as at North Blue Hill) from both the St. Croix and Ellsworth terranes. The Penobscot BaySmith Cove-North Blue Hill fault displaces contact metamorphic isograds (Fig. 2) developed around the Sedgwick pluton (number 5 on Fig. 2). The Sedgwick pluton has been dated as $419.5 \pm 1 \mathrm{Ma}$ (Late Silurian) by the U-Pb method on zircon by R.D. Tucker (Stewart et al., 1995). The fault zone developed before the South Penobscot Intrusive Suite (Stewart et al., 1988) that intrudes it, and the age of the South Penobscot pluton should be younger than the Sedgwick pluton. This is apparently true within the $\pm 6 \mathrm{Ma}$ uncertainty on the $424 \mathrm{Ma}$ $\mathrm{U}-\mathrm{Pb}$ age by conventional methods on zoned zircons from the youngest unit of the South Penobscot Intrusive Suite (number 4 on Fig. 1), a porphyritic non-foliated granite (Stewart et al., 1988, p. 91). The age of this zircon will be redetermined by the isotopic dilution method on small samples (R.D. Tucker, oral communication, 1995) to verify this geologic interpretation.

After intrusion, the border zone of the South Penobscot Intrusive Suite was highly stretched and sheared (Stewart et al., 1988, fig. 2A). When movement along the fault zone was impeded, possibly by continued crystallization of the rocks of the South Penobscot Intrusive Suite, the locus of faulting shifted northward to the Bagaduce-Perkins Hill fault zone (number 3 on Fig. 2) while continuing along the Penobscot Bay fault to the south. A large block $(8.5 \times 2.5 \mathrm{~km})$ of the Ellsworth terrane now located north of Castine on the northern side of the Bagaduce-Perkins Hill fault zone probably was moved northeast approximately $16 \mathrm{~km}$ from its original position (Stewart, in press).

\section{Penobscot Bay-North Castine and Turtle Head fault zones}

As right-lateral movement continued, the locus of faulting shifted northward along the North Castine splay of the
Penobscot Bay-North Castine fault zone (numbers 3 and 4 on Fig. 2). The Penobscot Bay-North Castine fault zone bounds the Islesboro block on the east, and the Turtle Head fault zone (number 5 on Fig. 2) bounds it on the west. The Islesboro block, about $40 \mathrm{~km}$ long and $8 \mathrm{~km}$ wide, is a composite of fault blocks that was moved right-laterally as a more or less coherent mass. Heat flow from the South Penobscot Intrusive Suite imposed contact metamorphism on all of the fault blocks along its western side, including the Islesboro block, and isograds are offset dextrally across several fault splays (Fig. 2). The Penobscot Bay-North Castine fault is cut off by the Turtle Head fault zone, and therefore is older.

The original location of most of the Islesboro block is not known, as no exactly similar rocks are known with certainty elsewhere in Maine. Berry and Osberg (1989) have postulated that equivalents to the Islesboro lithologies occur near Camden and Rockland, Maine, on the mainland southwest of Islesboro. However, movement along the Turtle Head fault zone to make Islesboro contiguous with outcrops on the mainland would be sinstral, not dextral as most kinematic indicators near the fault zone on the mainland and on Islesboro suggest. In the southern part of the Islesboro block, fault blocks (not shown on Fig. 1; Stewart, in press), up to $6 \mathrm{~km}$ long and 2 $\mathrm{km}$ wide and made up of the older volcanic rocks from the Ellsworth terrane, are shuffled along numerous faults with blocks of Islesboro cover sequence and basement. The fault blocks of volcanic rocks may have been moved dextrally northeastward up to $15 \mathrm{~km}$ along the Penobscot Bay fault from their original positions southwest of North Haven Island (Stewart, in press).

The youngest strike-slip movement along the boundary faults of the Islesboro block was along the Turtle Head fault zone. This Late Silurian(?) movement sheared, foliated, and then broke across the northern part of the South Penobscot Intrusive Suite (Stewart et al., 1988). However, the time when movement ceased along the Turtle Head fault zone is not known closely. North of Castine, lower amphibolite facies Silurian and Devonian contact metamorphism of rocks on both sides of the Turtle Head fault zone is similar, and differential or repeated movement has not been recognized. The Turtle Head fault zone is intruded by the Lucerne pluton (number 6 on Fig. 1) dated by $\mathrm{Pb}-\mathrm{U}$ methods on zircon (Wones, 1991a) as $380 \pm$ $4 \mathrm{Ma}$ (Middle Devonian). No evidence of movement along this fault was found in the Lucerne pluton, and movement likely ceased tens of millions of years before that pluton was emplaced.

Near Wesley in eastern Maine, Gates (1989) described a fault equivalent to the Turtle Head fault zone that juxtaposed the St. Croix terrane against Silurian rocks of a periGondwanan terrane like the Ellsworth terrane. Upper Silurian(?) conglomerate is deformed and stretched near this fault, which was intruded in the Late Silurian by the Pocomoonshine pluton (West et al., 1992c). Farther east, on Cookson Island in northernmost Passamaquoddy Bay, Upper Silurian roundstone conglomerate was deposited unconformably upon rocks of the St. Croix terrane north of a concealed fault bounding the St. Croix terrane and a juxtaposed peri-Gondwanan terrane.

Although there likely was a component of northwestward 
thrusting along fault zones like the Turtle Head, the principal movements were strike-slip. Highly sheared slivers of the younger volcanic rocks of the Ellsworth terrane are found in the Turtle Head fault zone along the western boundary of the Islesboro block, and between it and the St. Croix terrane. These blocks are 15 to $20 \mathrm{~km}$ southwest of their closest original positions 7 to $10 \mathrm{~km}$ north of Castine (Stewart, in press). Other fault blocks that moved up to $6 \mathrm{~km}$ along the northwestern side of the fault zone are shown in the map of the Orland quadrangle (Wones, 1991a). The presence of numerous juxtaposed slivers of St. Croix and Ellsworth terrane with near-vertical contacts along the Penobcot Bay-Smith Cove-North Blue Hill fault zone, the younger Bagaduce-Perkins Hill and North Castine fault zones, and the younger-still Turtle Head fault zone indicates prolonged strike-slip motion along the common boundary of the St. Croix and Ellsworth terranes at shallow crustal levels.

Lower and middle amphibolite facies regional metamorphic rocks that had been metamorphosed by the Early Silurian in the St. Croix terrane on the western side of Penobscot Bay are separated by the Turtle Head fault zone from greenschist facies rocks of the Islesboro block (Fig. 2). No evidence of Silurian metamorphism or thermal effects caused by hot St. Croix terrane rocks has been found in the Islesboro block east of the fault zone, although the St. Croix terrane rocks remained above argon closure temperatures for hornblende and muscovite until the Early Devonian (West et al., in press). All exposures of the highly metamorphosed and magnetic rocks of the St. Croix terrane close to the Turtle Head fault zone south of Belfast (Fig. 2) are beneath the sea, and the fault zone was located (Stewart, in press) on the basis of the contrast between highly magnetized St. Croix rocks and weakly magnetized rocks of the Islesboro block, as delineated by band-pass filtered aeromagnetic maps by J.D. Phillips (unpublished report, 1989; 1990).

\section{Orrington-Liberty thrust fault and Norumbega fault zone}

These faults are younger than the faults of known and probable Silurian age described above. The Orrington-Liberty thrust fault (number 6 on Fig. 2) is older than the $371 \pm 2$ Ma (Middle Devonian) granite of Mount Waldo (number 1 on Fig. 1) (Stewart et al., 1995) but younger than the migmatitic granite of Stricklen Ridge (number 7 on Fig. 1) and quartz diorite of Winterport (number 8 on Fig. 1), each of which contain zircon with Late Silurian to Early Devonian ages (412 士 $16 \mathrm{Ma}$ ) (Zartman and Gallego, 1979). West (1993) reported ${ }^{40} \mathrm{Ar} /{ }^{39} \mathrm{Ar}$ hornblende cooling ages of 395 to $385 \mathrm{Ma}$ (Early and Middle Devonian) for middle amphibolite facies rocks comprising the thrust sheet. Acadian deformation along the northeastern end of the Orrington-Liberty fault was described by Kaszuba and Wones (1985), Kaszuba (1986), and Kaszuba and Simpson (1989).

The Norumbega fault zone (number 7 on Fig. 2) is the youngest fault zone shown in the area. The Norumbega fault zone displaces early Paleozoic metamorphic rocks (Wones, 1991a, 1991b; Hussey et al., 1993) and the Middle Devonian Lucerne pluton (number 6 on Fig. 1) with combined dextral strike-slip motion of as much as $35 \mathrm{~km}$ (Wones and Stewart,
1976; Wones and Thompson, 1979; Wones and Ayuso, 1993). Post-metamorphic movements in the late Paleozoic and Mesozoic have also been described (Osberg et al., 1985; Ludman, 1986, 1991; Hubbard et al., 1991; West et al., 1992b, 1993; West and Lux, 1993).

\section{AtTitude of boundary faults at DEPTH}

The attitudes at depth of some of the faults described in this paper can be deduced from their mapped positions and from their inferred positions on vertical incidence seismic reflection profiles in the region (Fig. 1). A change in the velocity of refracted compressional seismic waves observed for the inferred position of a fault is supporting evidence in some places.

The Sennebec Pond thrust fault is deduced to become listric in the middle crust at a depth of 10 to $15 \mathrm{~km}$. This fault is interpreted to dip steeply southeast, parallel to cleavage in rocks near the fault trace. Near the southeastern end of seismic reflection profile 4 (Fig. 1), a weak reflector dipping southeast at about $35^{\circ}$ can be projected upward for $1.5 \mathrm{~km}$ to intersect the mapped position of the Sennebec Pond thrust fault. Projection eastward $18 \mathrm{~km}$ normal to the fault trace at a dip of $35^{\circ}$ to the position of the migrated north end of seismic reflection profile 8 (Fig. 3) gives a point at about $13 \mathrm{~km}$ depth. This location is about $5 \mathrm{~km}$ deeper than the position of numerous south-dipping reflectors on profile 8 . However, if the projected dip of the fault is decreased to $\sim 25^{\circ}$, the top of the dipping reflectors observed on seismic profile 8 can be interpreted to be the trace of the Sennebec Pond fault at depth (Fig. 3b). This interpretation would also explain why the package of reflectors in the middle of profile 8 remains at the same depth in the southern parts of that profile. This would be expected because the projected distance from the trace of the fault to seismic line 8 (Fig. 1) initially increases southward along the fault and then remains nearly the same along the rest of the fault trace. Supporting evidence (Stewart et al., 1993) is that the velocity of refracted compressional seismic waves on refraction line 1 shows an increase of $0.25 \mathrm{~km} / \mathrm{sec}$ at the postulated depth of the fault (Fig. 3b).

The image of the Sennebec Pond thrust fault also can be found in vertical incidence seismic reflection profile 3B (Figs. $1,4)$. The Sennebec Pond fault was intruded by the Lucerne pluton (number 6 on Fig. 1) near the north end of profile 3B, so the former trace of the fault must be projected across the space occupied by the pluton. The measured perpendicular distance between the projected trace of the fault and the northern end of profile $3 B$ is approximately $4 \mathbf{k m}$. If the average dip of the Sennebec Pond fault is $30^{\circ}$ to the southeast, the fault image would be expected to be at about $2 \mathrm{~km}$ depth. However, the pluton now occupies this position (Fig. 4b). If the image of the fault is projected another $4 \mathrm{~km}$ along profile $3 B$ it would be expected at about $4 \mathrm{~km}$ depth, where a band of mediumstrength reflectors occurs (Fig. 4b). If this band is the image of the Sennebec Pond thrust fault, the fault continues southeasterly with a shallow dip for about $12 \mathrm{~km}$. Rocks of the Penobscot Formation of the St. Croix terrane are allochthonous above the fault until the Turtle Head dextral strike-slip fault zone is reached. Luetgert and Mann (1990) found an increase 

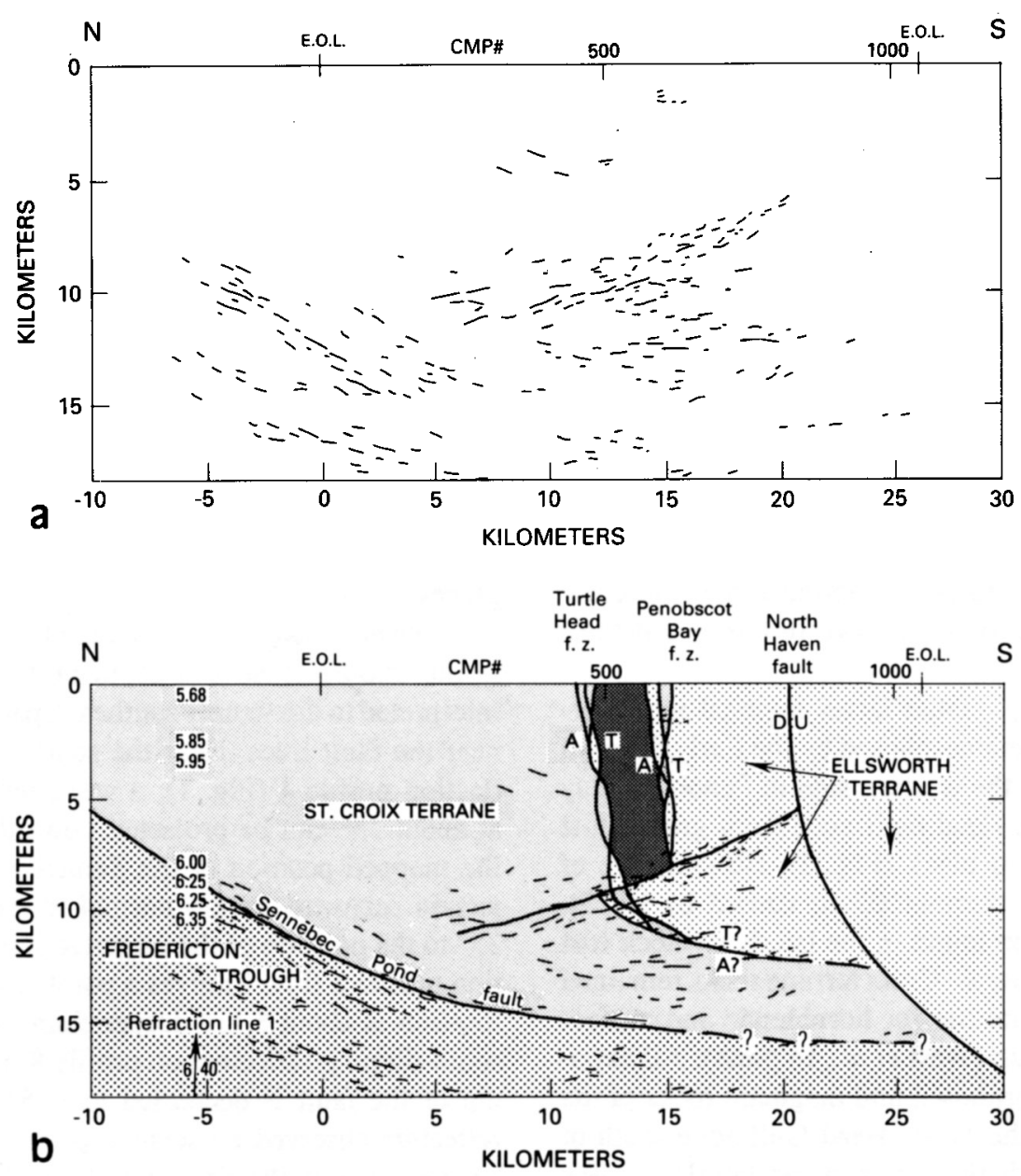

Fig. 3. (a) Line drawing prominent reflections in vertical incidence reflection profile 8 (USGS GYRE-85-11-8) migrated (Unger, 1988) using the velocity-depth function $5.98 \mathrm{~km} / \mathrm{sec} \times 0.027 \mathrm{sec}^{-1} \mathrm{z}$, where $\mathrm{z}$ is depth in $\mathrm{km}$. No vertical exaggeration. Data collected to $6 \mathrm{sec}$ two-way travel time, and processed by D.R. Hutchinson. For location of line 8 see Figure 1; CMP\#= common midpoint number, EOL = end of line. (b) Reflectors interpreted from geologic map (Fig. 1) following Stewart (in press). Refraction velocities at depth from refraction line 1 (Fig. 1) by J.H. Luetgert in Stewart et al. (1993). $A=$ fault motion away from observer; $T=$ fault motion toward observer; $\mathrm{D}=$ down; $U=$ up. Terranes are patterned as in Figure 1 .

in the velocity of the seismic refraction compressional wave of $0.1 \mathrm{~km} / \mathrm{sec}$ at the same depth as the interpreted position of the Sennebei Pond fault beneath the Turtle Head fault zone (Fig. 4b). South of the Turtle Head fault zone, the profile crosses rocks of the older Penobscot Bay-Smith Cove-North Blue Hill fault zone. These rocks are also interpreted to be allochthonous above the Sennebec Pond thrust fault. South of the North Blue Hill fault zone the Sennebec Pond fault zone at depth dips more steeply until at a depth of $\sim 10 \mathrm{~km}$, where it flattens and the image is less distinct. Here rocks of the Ellsworth terrane may be allochthonous, but the terrane affinity of the rocks beneath the fault is unknown. Many reflectors with gentle northwesterly dips are present in the middle crust below the fault. Similar reflectors occur in the middle crust beneath the sole of the fault on seismic reflection profile 4 (Unger et al., 1987) west of Penobscot Bay (Fig. 1). Isotopic evidence from plutons thought to have originated by melting of mid-crustal source rocks (Ayuso, 1986; Ayuso and Bevier, 1991) indicates that the mid-crustal rocks are radiogenic and suggests that they have peri-Gondwanan affinity.

Seismic reflection lines $3 \mathrm{~B}$ and 8 were planned to deter- mine the attitude of the Turtle Head fault zone at depth. The Turtle Head fault zone has a nearly vertical dip at the surface. However, no image was obtained of this fault zone or of the North Blue Hill fault, a splay of the Penobscot Bay fault zone on profile 3B. Probably neither of these fault zones penetrates deeper than approximately $5 \mathrm{~km}$ because at that depth on the profile a band of subhorizontal reflectors nearly $2 \mathrm{~km}$ thick extends uniformly for many kilometers both north and south of the traces of both fault zones. This band of reflectors was interpreted above as the image of the Sennebec Pond thrust fault. As the Turtle Head fault zone is interpreted to be younger than the Sennebec Pond fault and to have had principally dextral strike-slip movement, the Sennebec Pond fault is the surface along which translatory motions of blocks of the St. Croix and Ellsworth terranes occurred in and southwest of the Turtle Head fault zone. Lemiski and Brown (1988) described similar intra-plate strike-slip faults decoupled at mid-crustal depths.

Seismic reflection line 8 was almost parallel to the Turtle Head fault zone because of marine navigation requirements, and few shallow reflection data were obtained because of the irregular sea floor. Although the Turtle Head fault zone dips 

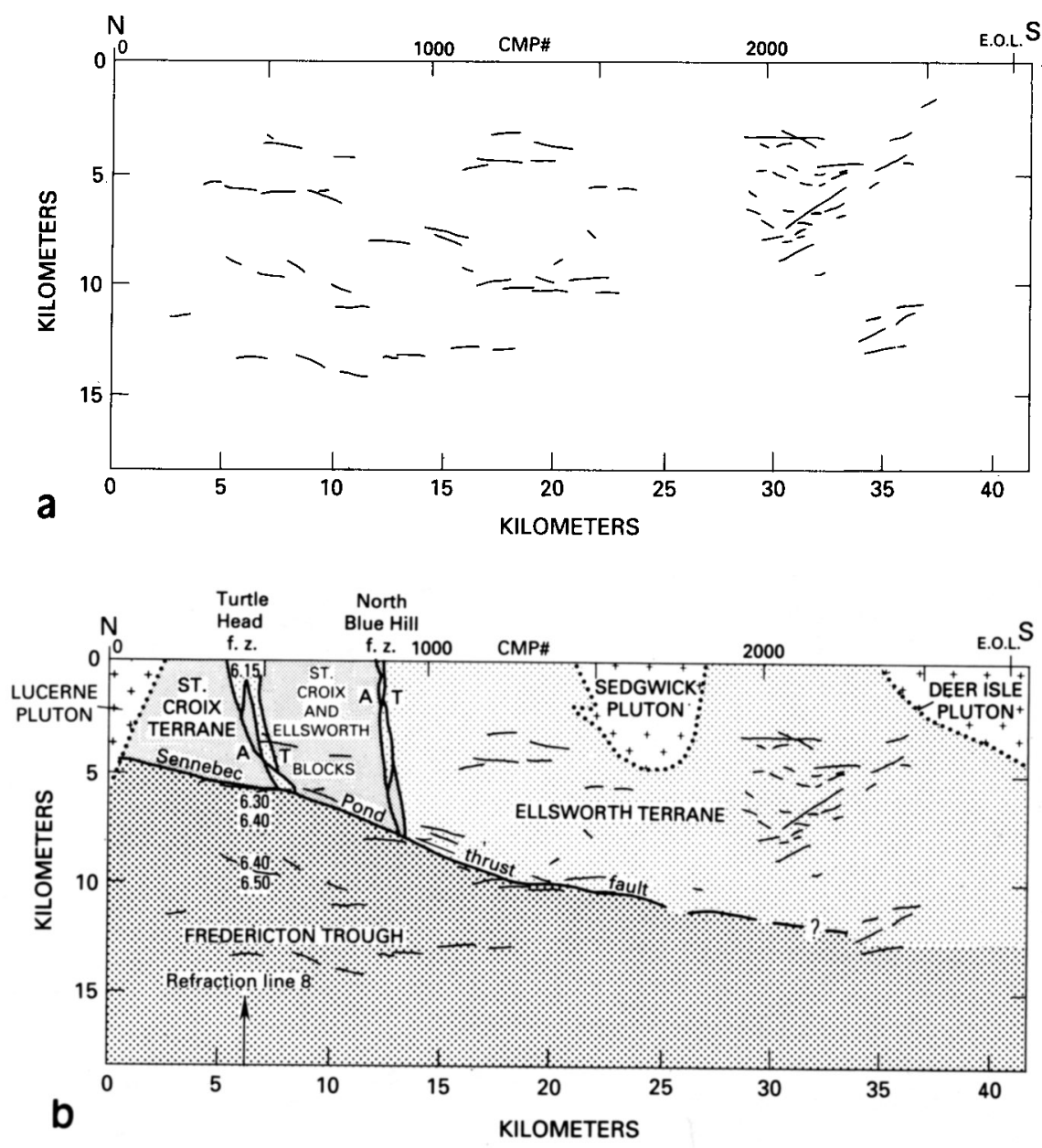

Fig. 4. (a) Line drawing prominent reflectors in shallow portion of vertical incidence reflection profile $3 \mathrm{~B}$ with migrated (Unger, 1988) with same velocities and scale as for Figure 3. No vertical exaggeration. For location of line $3 \mathrm{~B}$ see Figure 1 ; CMP\# = common midpoint number; EOL = end of line. (b) Reflectors interpreted following geological map (Fig. 1) and Stewart (in press). Refraction velocities at depth from refraction line 8 (Fig. 1), after Luetgert and Mann (1990). A = fault motion away from observer; $\mathrm{T}=$ fault motion toward observer. Terranes are patterned as in Figure 1 .

steeply at the surface, it does not disrupt strong bands of northdipping reflectors on the profile at a depth of $9 \mathrm{~km}$ (Figs. 3a, b) that were interpreted to be above the Sennebec Pond fault, itself thought to be at a depth of about $15 \mathrm{~km}$. The Turtle Head fault zone could remain steep until it reaches the Sennebec Pond fault, as it was interpreted to do along profile 3B (Fig. $3 b)$. Alternatively, it may dip less steeply to the south at depth and become listric in the Penobscot Formation above the Sennebec Pond thrust fault, as shown on Figure 3b. Under either interpretation, the St. Croix and Ellsworth terranes (and Islesboro block) are allochthonous parts of a plate 10 to 15 $\mathrm{km}$ thick that was initially a northwest-directed thrust sheet. During Middle Silurian to earliest Devonian(?) time, the Ellsworth terrane and Islesboro block portions of the allochthonous plate moved in translatory motion (Lemiski and Brown, 1988) into their present positions along the dextral Penobscot Bay strike-slip fault zone and its younger equivalents, the youngest of which is the Turtle Head fault zone.

It is possible that, if the Turtle Head fault zone remains steep, it could cut off the older Sennebec Pond fault at depth, in which case the Ellsworth terrane need not be thrust over the St. Croix terrane. This possibility seems less likely than the interpretations above because the numerous juxtaposed slivers of St. Croix and Ellsworth terranes with near-vertical contacts along all the strike-slip fault zones mapped in the East Penobscot Bay region indicate prolonged contact between the St. Croix and Ellsworth terranes at shallow crustal levels.

\section{Regional SPECULATions}

Silurian tectonic processes including large strike-slip and thrust faults, metamorphism and extensive plutonism are now well documented in New Brunswick, Nova Scotia and Newfoundland, and in northern Europe. This paper describes comparable Silurian events in coastal central Maine where metamorphosed Upper Ordovician and Lower Siluran rocks of the Fredericton trough were overthrust late in the Silurian by metamorphosed Ordovician and older rocks of the St. Croix terrane. The St. Croix and Ellsworth terranes (and the Islesboro block between them) then were juxtaposed by right-lateral strike-slip faults during the Late Silurian (and Early Devonian?) and intruded by Silurian plutons. Similar orogenic events are reported for southeastern New Hampshire (Bothner et al., 1993) and eastern Massachusetts (Goldsmith, 1991; Wones 
and Goldsmith, 1991; Hepburn et al., 1994). The SalinicCaledonide orogeny is now recognized to be very extensive and important, and to have occurred in peri-Gondwanan terranes outboard of the southeastern flank of ancestral North America prior to the onset of the Early Devonian Acadian orogeny (Soper et al., 1992).

The Acadian orogeny resulted in the addition of more terranes with Gondwanan affinities to the Salinic orogenic belt, and the accretion of the resulting composite terranes to ancestral North America (Dunning et al., 1990a, 1990b; O'Brien et al., 1991; West et al., 1992c; Nance and Dallmeyer, 1993; Rankin, 1994). The effects of Acadian deformation, metamorphism, and plutonism have obliterated much of the evidence of the earlier orogeny over many parts of both ancestral North America and Gondwana, but enough remains to warrant revision of earlier concepts for the formation of the northern Appalachian orogen. The location of the Acadian suture, if taken to be the southeastern flank of the Salinic orogenic belt, is southeast of the region described here, possibly along the Gulf of Maine fault zone described by Hutchinson et al. (1988). Ultramafic and mafic rocks intruded into folded and metamorphosed Penobscot Formation of the St. Croix terrane at Union, Maine (Fig. 1), $50 \mathrm{~km}$ southwest of Belfast, were emplaced as solid units according to Gaudette (1981): He obtained a zircon $\mathrm{Pb}-\mathrm{U}$ date of $410 \pm 7 \mathrm{Ma}$ (Early Devonian and Late Silurian) for a mafic intrusive rock. His suggestion that these rocks were emplaced along a cryptic suture marking obduction of oceanic crustal material along the Acadian suture is not supported by the present study. Another candidate location for an 'Acadian' suture would be along the northwestern flank of the Salinic orogen, presumably along its contact with the Central Maine synclinorium (Ludman et al., 1993, pp. 74-75). This contact, about $25 \mathrm{~km}$ northwest of the region described here, was interpreted to be the Hackmatack Pond Fault (Fig. 1) by Stewart et al. (1993).

Regional syntheses of the northern Appalachian orogen must take account of the extensive Late Silurian-Early Devonian orogenic belt in peri-Gondwanan composite terranes like that described in this paper that were formed outboard of terranes formed on or near ancestral North America, like the Central Maine synclinorium in which sedimentation was continuous from Late Ordovician to Early Devonian and Silurian metamorphism is absent. The peri-Gondwanan orogenic belt may have supplied Early Devonian flysch to basins on ancestral North America in the earliest stages of continental collision that led to the Acadian orogeny.

Ayuso, R.A. 1986. Lead-isotopic evidence for distinct sources of granite and distinct basements in the northern Appalachians, Maine. Geology, 14:4, pp. 322-325.

Ayuso, R.A. and Bevier, M.L. 1991. Regional differences in $\mathrm{Pb}$ isotopic compositions of feldspars in plutonic rocks of the northern Appalachian Mountains, U.S.A. and Canada: A geochemical method of terrane correlation. Tectonics, 10:1, pp. 191-212.

Berry, H.N., IV and OsBerg, P.H. 1989. A stratigraphic synthesis of eastern Maine and western New Brunswick. In Studies in Maine geology, volume 2: structure and stratigraphy.
Edited by R.D. Tucker and R.G. Marvinney. Maine Geological Survey, pp. 1-32.

Bevier, M.L. and Whalen, J.B. 1990. Tectonic significance of Silurian magmatism in the Canadian Appalachians. Geology, 18, pp. 411-414.

BiCKEL, C.E. 1976. Stratigraphy of the Belfast quadrangle, Maine. In Contributions to the stratigraphy of New England. Edited by L.R. Page. Geological Society of America, Memoir 148, pp. 97-128.

Boone, G.M. and Boudette, E.L. 1989. Accretion of the Boundary Mountains Terrane within the northern Appalachians orthotectonic zone. In Melanges and olistostromes of the U.S. Appalachians. Edited by J.W. Horton, Jr. and N. Rast. Geological Society of America, Special Paper 228, pp. 17 42.

Bothner, W.A., Gaudette, H.E., Fargo, T.G., Bowring, S.A., and IsACHSEN, G.E. 1993. Zircon and sphene U-Pb ages of the Exeter pluton: constraints on the Merrimack Group and part of the Avalon composite terrane. Geological Society of America, Abstracts with Programs, 25:6, p. A485.

Brookins, D.G. 1976. Geochronologic contributions to stratigraphic interpretation and correlation in the Penobscot Bay area, eastern Maine. In Contributions to the stratigraphy of New England. Edited by L.R. Page. Geological Society of America, Memoir 148, pp. 129-145.

Brookins, D.G., Berdan, J.M., and Stewart, D.B. 1973. Isotopic and paleontologic evidence for correlating three volcanic sequences in the Maine coastal volcanic belt. Geological Society of America, Bulletin 84:5, pp. 1619-1628.

Doig, R., Nance, R.D., Murphy, J.B., and Casseday, R.P. 1990. Evidence for Silurian sinistral accretion of Avalon composite terrane in Canada. Journal of the Geological Society, London, 147, pp. 927-930.

Dubé, B., Dunning, G.R., Lauziere, K., and Roddick, C. 1993. The Gondwanan-Laurentian suture: Timing of deformation on the Cape Ray fault, Newfoundland Appalachians. Geological Society of America, Abstracts with Programs, 25:6, p. A421

Dunning, G.R., Barr, S.M., Raeside, R.P., and Jamieson, R.A. 1990a. U-Pb zircon, titanite and monazite ages in the Bras d'Or and Aspy terranes of Cape Breton Island, Nova Scotia: Implications for magmatic and metamorphic history. Geological Society of America, Bulletin 102, pp. 322-330.

Dunning, G.R., O'Brien, S.J., Colman-Sadd, S.P., Blackwood, R.F., Dickson, W.L., O'NeILl, P.P., and KROGH, T.E. 1990 b. Silurian orogeny in the Newfoundland Appalachians. Journal of Geology, 98, pp. 895-913.

Dunning, G.R., O'Brien, S.J., O'Brien, B.H., Holdsworth, R.E., and Tucker, R.D. 1993. Chronology of Pan-African, Penobscot and Salinic shear zones on the Gondwanan margin, northern Appalachians. Geological Society of America, Abstracts with Programs, 25:6, pp. A421-A422.

Eby, G.N. and Currie, K.L. 1993. Petrology and geochemistry of the Kingston complex - a bimodal sheeted dyke suite in southern New Brunswick. Atlantic Geology, 29, pp. 121-135.

Ericksson, S.C., Hogan, J.P., and Williams, I.S. 1989. Ion microprobe resolution of age details in heterogeneous sources of plutonic rocks from a comagmatic province. Geological Society of America, Abstracts with Programs, $21: 6$, p. A361.

FYFFE, L.R. 1992a. Revised stratigraphy of early Paleozoic rocks in the Piskahegan Stream-Mount Pleasant area of southwestern New Brunswick. Atlantic Geology, 28:2, pp. 197-198.

1992b. Geology of the Flume Ridge-Kedron Stream map areas, Charlotte County, New Brunswick. In Project sum- 
maries for 1991, Sixteenth annual review of activities. $E d$ ited by S.A. Abbott. New Brunswick Department of Natural Resources and Energy, Information Circular 91-2, pp. 12-20.

FYFFE, L.R. and RIVA, J. 1990. Revised stratigraphy of the Cookson Group of southwestern New Brunswick and adjacent Maine. Atlantic Geology, 26:5, pp. 271-275.

Fyffe, L.R., Stewart, D.B., and Ludman, A. 1988. Tectonic significance of black pelites and basalts in the St. Croix terrane, coastal Maine and New Brunswick. Maritime Sediments and Atlantic Geology, 24:3, pp. 281-288.

GATES, O. 1989. Silurian roundstone conglomerates of coastal Maine and adjacent New Brunswick. In Studies in Maine geology, volume 2, structure and stratigraphy. Edited by R.D. Tucker and R.G. Marvinney. Maine Geological Survey, pp. 127-144.

GaudetTe, H.E. 1981. Zircon isotopic age from the Union ultramafic complex, Maine. Canadian Journal of Earth Sciences, 18:2, pp. 405-409.

Goldsmith, R. 1991. (H) Structural and metamorphic history of eastern Massachusetts. In The Bedrock Geology of Massachusetts. Edited by N.L. Hatch, Jr. U.S. Geological Survey, Professional Paper 1366-E-J, pp. H1-H63.

Goldsmith, R. and SECOR, D.J., Jr. 1993. Proterozoic rocks of accreted terranes in the eastern United States. In Precambrian: Conterminous. Edited by J.L. Reed, Jr., M.E. Bickford, R.S. Houston, P.K. Link, D.W. Rankin, P.K. Sims, and W.R. Van Schmus. U.S. Geological Society of America, The Geology of North America, v. C-2, pp. 422-438.

GuidotTi, C.V. 1989. Metamorphism in Maine: An overview. In Studies in Maine geology, volume 3: igneous and metamorphic geology. Edited by R.D. Tucker and R.G. Marvinney. Maine Geological Survey, pp. 1-17.

Hepburn, J.C., Dunning, G.R., and Hon, R. 1994. Silurian onset of the "Acadian" orogeny: Tectonic implications from the Nashoba terrane, SE New England. Geological Society of America, Abstracts with Programs, 26:7, p. Al37.

Hubbard, M.S., West, D.P., JR., LuX, D.R., Orifice, J., GuidotTI, C.V., Higgins, K., and YanAsak, J. 1991. Major dextral strikeslip deformation in the northern Appalachians: the Norumbega fault zone Maine. Geological Society of America, Abstracts with Programs, 23:5, p. A311.

HusSEY, A.M., II. 1989. Geology southwestern coastal Maine. In Neotectonics of Maine. Edited by W.A. Anderson and H.W. Borns, Jr. Maine Geological Survey, Bulletin 40, pp. 25 42.

Hussey, A.M., II, Aleinikoff, J., and Marvinney, R.G. 1993. Reinterpretation of age and correlation between tectonostratigraphic units, southwestern Maine. Geological Society of America, Abstracts with Programs, 25:2, p. 25.

Hutchinson, D.R., Klitgord, K.D., LeE, M.W., and Trehu, A.M. 1988. U.S. Geological Survey deep seismic reflection profile across the Gulf of Maine. Geological Society of America, Bulletin 100:2, pp. 172-184.

Kaszuba, J.P. 1986. Polyphase deformation and metamorphism in the Penobscot Bay area, coastal Maine. Unpublished M.Sc. thesis, Virginia Polytechnic Institute and State University, Blacksburg, $100 \mathrm{p}$.

Kaszuba, J.P. and Simpson, C. 1989. Polyphase deformation in the Penobscot Bay area, coastal Maine. In Studies in Maine geology, volume 2, structure and stratigraphy. Edited by R.D. Tucker and R.G. Marvinney. Maine Geological Survey, pp. 145-161.

KaszubA, J.P. and Wones, D.R. 1985. Early Devonian thrusting in the Penobscot Bay area, Maine. Geological Society of
America, Abstracts with Programs, 17:1, p. 27.

KLemperer, S.L. and Luetgert, J.H. 1987. A comparison of reflection and refraction processing and interpretation methods applied to conventional refraction data from coastal Maine. Seismological Society of America Bulletin, 77:2, pp. 614 630.

Lemiski, P.J. and Brown, L.D. 1988. Variable crustal strike-slip fault zones as observed on deep seismic reflection profiles. Geological Society of America Bulletin, 100, pp. 665-676.

Ludman, A. 1986. Timing of terrane accretion in eastern and east-central Maine. Geology, 14, pp. 411-414.

- 1987. Pre-Silurian stratigraphy and tectonic significance of the St. Croix Belt, southeastern Maine. Canadian Journal of Earth Sciences, 24:12, pp. 2459-2469.

- 1991. Revised stratigraphy of the Cookson Group in eastern Maine and southwestern New Brunswick, an alternative view. Atlantic Geology, 27:1, pp. 49-55.

Ludman, A., Hopeck, J.T., and Brock, P.C. 1993. Nature of the Acadian orogeny in eastern Maine. In The Acadian Orogeny: Recent Studies in New England, Maritime Canada, and the Autochthonous Foreland. Edited by D.C. Roy and J.W. Skehan. Geological Society of America, Special Paper 275, pp. 67-84.

Luetgert, J.H. and MANn, C.E. 1990. Avalon terrane in eastern coastal Maine, seismic refraction-wide-angle reflection data. Geology, 18:9, pp. 878-881.

Nance, R.D. and Dallmeyer, R.D. $1993 .{ }^{40} \mathrm{Ar} /{ }^{39} \mathrm{Ar}$ amphibolite ages from the Kingston complex, New Brunswick: Evidence for Silurian-Devonian tectonothermal activity and implications for the accretion of the Avalon composite terrane. Journal of Geology, 101, pp. 375-388.

Neuman, R.B. and Harper, D.T. 1992. Paleogeographic significance of Arenig-Llanvirn Toquima-Table Head and Celtic brachiopod assemblages. In Global perspectives on Ordovician geology. Edited by B.D. Webby and J.R. Laurie. Balkema, Rotterdam, pp. 241-254.

O'Brien, B.H., O'Brien, S.J., and Dunning, G.R. 1991. Silurian cover, Late Precambrian-Early Ordovician basement, and the chronology of Silurian orogenesis in the Hermitage flexure (Newfoundland Appalachians). American Journal of Science, 291, pp. 760-799.

OsBerg, P.H. and BERRY, H.N., IV. 1991. Stratigraphy of lithotectonic belts west of Penobscot Bay, Maine. In Geology of the coastal lithotectonic block and neighboring terranes, eastern Maine and southern New Brunswick. Edited by A. Ludman. New England Intercollegiate Geological Conference Guidebook, 83rd Annual Meeting, Princeton, Maine, pp. 358-373.

Osberg, P.H., Hussey, A.M., II, and Boone, G.M. 1985. Bedrock geologic map of Maine: Augusta, Maine. Maine Geological Survey, scale 1:500,000.

PhILLIPS, J.D. 1990. Integration of potential-field and digital geologic data for two North American Geoscience Transects. Journal of Geological Education, 38, pp. 330-338.

Rankin, D.W. 1994. Continental margin of the eastern United States, past and present. In Phanerozoic evolution of North American continent-ocean transitions. Edited by R.C. Speed. Geological Society of America, DNAG Continent-Ocean Transect volume, Chapter 3, pp. 129-218.

Reynolds, P.H., Jamieson, R.A., BARR, S.M., and Raeside, R.P. 1989. An ${ }^{40} \mathrm{Ar} /{ }^{39} \mathrm{Ar}$ study of the Cape Breton Highlands, Nova Scotia: thermal histories and tectonic implications. Canadian Journal of Earth Sciences, 26, pp. 2081-2091.

Ruitenberg, A.A., McLeod, M.J., and Krogh, T.E. 1993. Comparative metallogeny of Ordovician volcanic and sedimentary rocks in the Annidale-Shannon (New Brunswick) and 
Harborside-Blue Hill (Maine) areas, implications of new $\mathrm{U}-\mathrm{Pb}$ age dates. Exploration and Mining Geology, 2:4, pp. 355-365.

Seaman, S.J., Wobus, R.A., Wiebe, R.A., Lubick, N., and Bowring, S.A. 1995. Volcanic expression of bimodal magmatism: the Cranberry Island-Cadillac Mountain Complex, coastal Maine. Journal of Geology, 103, pp. 301-311.

Secor, D.T., JR., Murray, D.P., and Glover, L., III. 1989. Geology of the Avalonian rocks. In The Appalachian-Ouachita orogen in the United States: Boulder, Colorado. Edited by R.D. Hatcher, Jr., W.A. Thomas, and G.W. Viele. Geological Society of America, the Geology of North America, F-2, pp. 57-85.

Soper, N.J., Strachan, R.A., Holdsworth, R.E., Gayer, R.A., and Greiling, R.O. 1992. Sinstral transpression and the Silurian closure of Iapetus. Journal of the Geological Society London, 149, pp. 871-880.

Spencer, C., Green, A., Morel-A-l'Huissier, P., Luetgert, J.H., Stewart, D.B., Unger, J.D., and Phillips, J.D. 1989. The extension of Grenville basement beneath the northern Appalachians: Results from the Quebec-Maine seismic reflection and refraction surveys. Tectonics, 8, pp. 677-696.

Stewart, D.B. In press. Bedrock geologic map of northern Penobscot Bay, south-central Maine. U.S. Geological Survey, Miscellaneous Investigations, Series Map I-2551.

Stewart, D.B. and Lux, D.R. 1988. Lithologies and metamorphic age of the Precambrian rocks of Seven Hundred Acre Island and vicinity, Islesboro, Penobscot Bay, Maine. Geological Society of America, Abstracts with Programs, 20:1, p. 73.

Stewart, D.B., Arth, J.G., and Flohr, M.J.K. 1988. Petrogenesis of the South Penobscot Intrusive Suite, Maine. American Journal of Science, 288-A, pp. 75-114.

Stewart, D.B., Wright, B.E., Unger, J.D., Phillips, J.D., and HUtchinson, D.R. 1993. Global geoscience transect 8, Quebec-Maine-Gulf of Maine transect, southeastern Canada, northeastern United States of America. U.S. Geological Survey, Miscellaneous Investigations, Series Map I-2329, scale $1: 1,000,000$.

Stewart, D.B., Tucker, R.D., and West, D.P., JR. 1995. Genesis of Silurian composite terrane in northern Penobscot Bay. In Guidebook for field trips in southern Maine and adjacent New Hampshire. Edited by A.M. Hussey, II. and R. Johnston. New England Intercollegiate Geological Conference, 87th Annual Meeting, Brunswick, Maine, pp. A3-1 to A3-21.

TUCKer, R.D. and McKerrow, W.S. 1995. Early Paleozoic chronology: a review in light of new U-Pb zircon ages from Newfoundland and Britain. Canadian Journal of Earth Sciences, 32, pp. 368-379.

UNGER, J.D. 1988. A PC program for migration of seismic reflection profiles. Geobyte, August, 1988, pp. 42-54.

Unger, J.D., Stewart, D.B., and Phillips, J.D. 1987. Interpretation of migrated seismic reflection profiles across the northern Appalachians in Maine. Geophysical Journal Royal Astronomical Society, 89:1, pp. 171-176.

van StaAl, C.R. 1987. Tectonic setting of the Tetagouche Group in northern New Brunswick: Implications for plate tectonic models of the northern Appalachians. Canadian Journal of Earth Sciences, 24, pp. 1329-1351.

1993. Classification of structures in the Appalachians on basis of absolute age - a dangerous legacy of fixism. Geological Society of America, Abstracts with Programs, 25:6, p. A178.

1994. Brunswick subduction complex in the Canadian Ap- palachians: Record of the Late Ordovician to Late Silurian collision between Laurentia and the Gander margin of Avalon. Tectonics, 13:4, pp. 946-962.

van StaAl, C.R. and FyfFe, L.R. 1991. Dunnage and Gander Zones, New Brunswick: Canadian Appalachian Region. New Brunswick Department of Natural Resources and Energy, Mineral Resources, Geoscience Report 91-2, pp. 1-39.

van StaAl, C.R. and Williams, H. 1992. Dunnage-Gander relations in the Appalachian orogen: Evidence for an Early Ordovician arc-continent collision. Geological Association of Canada/Mineralogical Association of Canada, Abstracts, 17, pp. A112-A113.

WEST, D.P., JR. 1993. The eastern limit of Acadian high grade metamorphism in northern New England: Implications for the location of the "Acadian Suture". Geological Society of America, Abstracts with Programs, 25:2, p. 89.

West, D.P., JR. and Lux, D.R. 1993. Dating mylonitic deformation by the ${ }^{40} \mathrm{Ar} /{ }^{39} \mathrm{Ar}$ method: an example for the Norumbega fault zone, Maine. Earth and Planetary Science Letters, 120:34, pp. 221-237.

West, D.P., JR., GuiDotri, C.V., and LuX, D.R. 1992a. ${ }^{40} \mathrm{Ar} /{ }^{39} \mathrm{Ar}$ mineral ages from southwestern Penobscot Bay, Maine, evidence for Silurian metamorphism. Geological Society of America, Abstracts with Programs, 24:7, p. A289.

West, D.P., JR., Hubbard, M.S., and Lux, D.R. 1992b. Geochronological and structural evidence for differential movement along the Norumbega fault zone, south-central Maine. Geological Association of Canada/Mineralogical Association of Canada, Abstracts, 17, p. Al16.

West, D.P., JR., Ludman, A., and Lux, D.R. 1992c. Silurian age for the Pocomoonshine gabbro-diorite and its regional tectonic implications. American Journal of Science, 292:4, pp. 253-273.

West, D.P., JR., Lux, D.R., and Hussey, A.M., II. 1993. Contrasting thermal histories across the Flying Point fault, southwestern Maine: Evidence for Mesozoic displacement. Geological Society of America Bulletin, 105:11, pp. 1478-1490.

West, D.P., JR., GuidotTI, C.V., and LUX, D.R. In press. Silurian orogenesis in the western Penobscot Bay region, Maine. Canadian Journal of Earth Sciences.

Westerman, D.S. 1991. Mafic and ultramafic rocks of the Pocomoonshine gabbro-diorite in southeastern Maine. In Geology of the coastal lithotectonic block and neighboring terranes, eastern Maine and southern New Brunswick. Edited by A. Ludman. New England Intercollegiate Geological Conference Guidebook, 83rd Annual Meeting, Princeton, Maine, pp. 265-284.

Wones, D.R. 1991a. Bedrock geologic map of the Orland quadrangle, Hancock and Penobscot Counties, Maine. U.S. Geological Survey, Geologic Quadrangle Map GQ-1691, scale 1:62,500. 1991b. Bedrock geologic map of the Bucksport quadrangle, Waldo, Hancock, and Penobscot Counties, Maine. U.S. Geological Survey, Geologic Quadrangle Map GQ-1692, scale 1:62,500.

Wones, D.R. and Ayuso, R.A. 1993. Geologic map of the Lucerne Granite, Hancock and Penobscot Counties, Maine. U.S. Geological Survey, Miscellaneous Investigations Series Map I-2360, scale 1:125,000.

WONES, D.R. and GoLDSMITH, R. 1991. (I) Intrusive rocks of eastern Massachusetts. In The Bedrock Geology of Massachusetts. Edited by N.L. Hatch, Jr. U.S. Geological Survey, Professional Paper 136-E-J, pp. I1-I61.

Wones, D.R. and Stewart, D.B. 1976. Middle Paleozoic regional right-lateral strike-slip faults in central coastal Maine. Geological Society of America, Abstracts with Programs, 8:2, p. 304. 
Wones, D.R. and Thompson, W. 1979. The Norumbega fault zone, a major regional structure in central eastern Maine. Geological Society of America, Abstracts with Programs, 11:1, p. 60 .
Zartman, R.E. and Gallego, M.D. 1979. In Radiometric ages: Compilation B. Edited by R.F. Marvin and S.W. Dobson. U.S. Geological Survey, Isochron West, 26, p. 18.

Editorial Responsibility: S.M. Barr 